\title{
Soil carbon sequestration and changes in fungal and bacterial biomass following incorporation of forest residues
}

\author{
Matt D. Busse ${ }^{\mathrm{a}, *}$, Felipe G. Sanchez ${ }^{\mathrm{b}}$, Alice W. Ratcliff ${ }^{\mathrm{a}}$, John R. Butnor ${ }^{\mathrm{c}}$, Emily A. Carter ${ }^{\mathrm{d}}$, \\ Robert F. Powers ${ }^{\text {a }}$ \\ ${ }^{a}$ USDA Forest Service, Pacific Southwest Research Station, 3644 Avtech Parkway, Redding, CA 96002, USA \\ ${ }^{\mathrm{b}}$ USDA Forest Service, Southern Research Station, Research Triangle Park, NC 27709, USA \\ ${ }^{c}$ USDA Forest Service, Southern Research Station, South Burlington, VT 05403, USA \\ ${ }^{\mathrm{d}}$ USDA Forest Service, Southern Research Station, Auburn, AL 36849, USA
}

\section{A R T I C L E I N F O}

\section{Article history:}

Received 30 July 2008

Received in revised form

29 September 2008

Accepted 13 October 2008

Available online 6 November 2008

\section{Keywords:}

Soil carbon

Microbial biomass

Harvesting

Fuel reduction methods

Fluorescent microscopy

\begin{abstract}
A B S T R A C T
Sequestering carbon (C) in forest soils can benefit site fertility and help offset greenhouse gas emissions. However, identifying soil conditions and forest management practices which best promote $\mathrm{C}$ accumulation remains a challenging task. We tested whether soil incorporation of masticated woody residues alters short-term $C$ storage at forested sites in western and southeastern USA. Our hypothesis was that woody residues would preferentially stimulate soil fungal biomass, resulting in improved $C$ use efficiency and greater soil $\mathrm{C}$ storage. Harvest slash at loblolly pine sites in South Carolina was masticated (chipped) and either (1) retained on the soil surface, (2) tilled to a soil depth of $40 \mathrm{~cm}$, or (3) tilled using at least twice the mass of organics. At comparative sites in California, live woody fuels in ponderosa pine stands were (1) masticated and surface applied, (2) masticated and tilled, or (3) left untreated. Sites with clayey and sandy soils were compared in each region, with residue additions ranging from 20 to $207 \mathrm{Mg} \mathrm{ha}^{-1}$ Total and active fungal biomass were not strongly affected by residue incorporation despite the high input of organics. Limited response was also found for total and active bacterial biomass. As a consequence, fungal:bacterial (F:B) biomass ratios were similar among treatments at each site. Total soil $\mathrm{C}$ was elevated at one California site following residue incorporation, yet was significantly lower compared to surface-applied residues at both loblolly pine sites, presumably due to the oxidative effects of tilling on soil organic matter. The findings demonstrated an inconsequential effect of residue incorporation on fungal and bacterial biomass and suggest a limited potential of such practices to enhance long-term soil $\mathrm{C}$ storage in these forests.
\end{abstract}

Published by Elsevier Ltd.

\section{Introduction}

Soil organic matter has long been revered as a critical constituent of soil physical, chemical, and biological quality (Doran and Parkin, 1994; Stevenson, 1994; Jurgensen et al., 1997; Nambiar, 1997; Grigal, 2000). Societal concerns for global warming have further sparked interest in soils and their ability to sequester $\mathrm{C}$ in stable organic forms to mitigate increasing atmospheric $\mathrm{CO}_{2}$ concentrations (Lal, 2001). While not a panacea for mitigating global warming (Swift, 2001), opportunities for increasing soil C storage have been projected and are receiving considerable scrutiny from the scientific community, land managers, and policy analysts

\footnotetext{
This article was written and prepared by U.S. Government employees on official time and it is, therefore, in the public domain and not subject to copyright.

* Corresponding author. Tel.: +1 530226 2530; fax: +1 5302265091.

E-mail address: mbusse@fs.fed.us (M.D. Busse).
}

(Kimble et al., 2003). Increasing C storage in forest ecosystems may not come easily, however, as the mechanisms that control the input of detrital $C$ and the internal cycling of soil organic matter are complex (Stevenson, 1994). This is best recognized by the variable response of soil $C$ storage to forest management practices such as afforestation, fire, harvesting, and vegetation control (Richter et al., 1999; Johnson and Curtis, 2001; Sanchez et al., 2006).

Forest soil C levels are predicated by the balance between organic matter inputs (plant residues) and losses (microbial decomposition, fire-induced consumption, erosion, and leaching), which vary by climate, disturbance regime, plant and microbial community composition, soil parent material, and time (Jenny, 1994). Studies in forest and grassland ecosystems highlight the importance of microbial community structure and, in particular, fungal:bacterial (F:B) ratios in regulating soil C storage (Sakamoto and Oba, 1994; Bailey et al., 2002; Brant et al., 2006; Högberg et al., 2007). Six et al. (2006) noted that fungal-dominated soils have slow $\mathrm{C}$ turnover rates because (1) fungi incorporate more $\mathrm{C}$ into biomass 
than bacteria, (2) they have more recalcitrant cell walls than bacteria, and (3) they facilitate $C$ stabilization and protection by enhancing soil aggregation. In addition, fungi are traditionally credited with greater growth efficiency (biomass production/ respiration) compared to bacteria, although this putative attribute was recently refuted as a mechanism for increased $C$ storage (Thiet et al., 2006).

Coupled with the premise that fungal-dominated soils enhance $\mathrm{C}$ storage are observations that $\mathrm{F}: \mathrm{B}$ ratios can be manipulated by management practices. A good example is the decline in fungal dominance in cultivated soils compared to native and no-till soils (Frey et al., 1999; Bailey et al., 2002). Likewise, the surface addition of woody residues in conifer forests (Brant et al., 2006) and the addition of high $\mathrm{C} / \mathrm{N}$ substrates (Bossuyt et al., 2001) were shown to increase $F: B$ ratios, while declines in $F: B$ ratios were found following $\mathrm{N}$ fertilization and herbicide applications (Bardgett et al., 1996; Frey et al., 2004; de Vries et al., 2006; Ratcliff et al., 2006). Collectively, these observations suggest that coarse-scale microbial community structure is pliable and may influence $C$ storage.

The charge remains to identify forest management practices that not only affect $F: B$ ratios and soil $C$ storage, but that are environmentally sound, practical, and cost effective. Afforestation of degraded agricultural soils is a potential candidate. Estimates of potential C sequestration are considerable (Heath et al., 2003), although early evidence from studies of soil C accumulation following forest conversion is inconsistent (Richter et al., 1999; Paul et al., 2002; Wang et al., 2006). Incorporating harvest residues in mineral soil also offers promise for improving long-term $C$ storage. Buford and Stokes (2000) suggested that incorporating residual slash from short-rotation hybrid poplar plantations may increase soil $\mathrm{C}$ concentrations without incurring excessive costs. Using a predictive model of carbon accumulation (CO2FIX), Buford and Stokes (2000) estimated a $60 \%$ increase in soil C storage during simulation runs of incorporated harvest slash from consecutive poplar rotations. Early results from related field studies, in fact, support their predictions. Sanchez et al. $(2000,2003)$ found moderate increases in soil C concentration at several study sites in the initial 1.5 years after incorporation of loblolly pine (Pinus taeda) slash.

The aim of our study was to determine whether incorporating forest residues would preferentially increase fungal biomass and promote an environment capable of storing more C. The loblolly pine sites of Sanchez et al. (2003) in South Carolina, USA were used to test this objective, along with two ponderosa pine (Pinus ponderosa) sites in the Mediterranean climate of western California. Study installations in both regions included sites of contrasting soil texture (clayey versus sandy soil) to compare relative changes in microbial community structure and $\mathrm{C}$ storage as a function of the soil physical environment.

\section{Materials and methods}

\subsection{California study sites and treatment design}

Two sites were located in northern California on the western slope of the Sierra Nevada (CA-1) and the Cascade Range (CA-2). They are part of a larger study examining the effects of alternative fuel reduction methods on ecosystem function at the forest-urban interface (http://www.fs.fed.us/psw/programs/ecology_of_western_forests/projects/fuel_reduction/). The climate is Mediterranean with cool, wet winters and warm, dry summers. Mean annual temperature at CA- 1 is $15^{\circ} \mathrm{C}$ with $65 \mathrm{~cm}$ of annual precipitation. Mean annual temperature at CA-2 is $10^{\circ} \mathrm{C}$ with $160 \mathrm{~cm}$ of annual precipitation. The soil at CA-1 is a Cohasset clay loam (fine-loamy mixed superactive mesic Ultic Haploxeralf) with a $\mathrm{pH}$ of 6.2 and an organic matter content of $142 \mathrm{~g} \mathrm{~kg}^{-1}$. The soil at CA-2 is a Washougal sandy loam (medial amorphic mesic Pachic Melanoxerand), with a pH of 6.9 and an organic matter content of $85 \mathrm{~g} \mathrm{~kg}^{-1}$. Site productivity for ponderosa pine is high at CA-1 $\left(\mathrm{SI}_{50}=36 \mathrm{~m}\right)$ and moderate at $\mathrm{CA}-2\left(\mathrm{SI}_{50}=30 \mathrm{~m}\right)$. The stands at both sites were 25 - to 40 -year-old ponderosa pine plantations, with understory vegetation comprised of either an extremely dense layer of hardwood trees and shrubs (CA-1) or a moderately dense layer of woody shrubs (CA-2).

Three treatments were installed at CA- 1 in 2001 and at CA- 2 in 2003. Understory vegetation was either left untreated (NT); masticated with all residues retained on the soil surface (S); or masticated with residues incorporated to a soil depth of $20 \mathrm{~cm}$ (I). Plot size was 0.4 ha, with four replicates of each treatment arranged in a randomized block experimental design. A Rayco mower/ mulcher (Wooster, OH, USA) was used to masticate understory trees and woody shrubs, producing chips of irregular shape from 1 to $5 \mathrm{~cm}$ in width and 3 to $15 \mathrm{~cm}$ in length. Chips were incorporated in the mineral soil using an industrial rototiller attached to a farm tractor. Estimated dry mass for S and I treatments was $75 \mathrm{Mg} \mathrm{ha}^{-1}$ at CA- 1 and $20 \mathrm{Mg} \mathrm{ha}^{-1}$ at CA-2 (R. Powers, data on file).

\subsection{South Carolina study sites and treatment design}

Two sites (SC-1, SC-2) were selected within the Department of Energy's Savannah River Site, a National Environmental Research Park, located in Aiken, Barnwell, and Allendale counties in the South Carolina upper Coastal Plain $\left(33^{\circ} 025^{\prime} \mathrm{N}, 81^{\circ} 2550^{\prime} \mathrm{W}\right)$. The sites are within $5 \mathrm{~km}$ of each other, and were in agricultural production until their conversion to loblolly and longleaf pine (Pinus palustris) plantations in the early 1950s. The climate is subtropical with an average annual temperature of $18^{\circ} \mathrm{C}$ and annual precipitation of $121 \mathrm{~cm}$ spread throughout the year. The soil at SC-1 is a clay, characterized by a shallow surface layer of $30 \mathrm{~cm}$ or less overlying an argillic horizon, and is in the Orangeburg (fine-loamy, kaolinitic, thermic Typic Kandiudults) and Dothan (fine-loamy, kaolinitic, thermic Plinthic Kandiudults) soil series. The soil at SC-2 is a sand ( $<10 \%$ clay and silt content), characterized by a deep sandy surface layer between 85 and $130 \mathrm{~cm}$ overlying an argillic horizon, and is classified as either Blanton (loamy, siliceous, semiactive thermic, Grossarenic Paleudults) or Fuquay (loamy, kaolinitic, thermic, Arenic Plinthic Kandiudults) soil series. Both soils are moderately acidic ( $\mathrm{pH} 4.6-5.1)$ and have low $\mathrm{C}$ concentrations (0.5$\left.1.0 \mathrm{~g} \mathrm{~kg}^{-1}\right)$. Site productivity for loblolly pine is poor $\left(\mathrm{SI}_{50}=27\right.$ and $25 \mathrm{~m}$ for SC-1 and SC-2 sites, respectively).

Three treatments were installed at each site following clearcut harvesting in 1999. Slash ( $>15 \mathrm{~cm}$ diameter) was removed off the plots. The residual debris and stumps were either replaced on the soil surface (S); incorporated as masticated chips to a depth of $40 \mathrm{~cm}$ using a CMI RS-500 road reclaimer (CMI Corp., Oklahoma City) (I); or incorporated with at least twice the mass of masticated residues (I2). Wood chips ranged from 1 to $7 \mathrm{~cm}$ in width and 3 to $20 \mathrm{~cm}$ in length. Plot size was 0.2 ha, with four replicates of each treatment per site arranged in a completely randomized experimental design. Additional wood-chip residues for the I2 plots were obtained from adjacent powerline clearing operations. Residue dry matter was estimated respectively at $28.5,32.2$, and $67.2 \mathrm{Mg} \mathrm{ha}^{-1}$ for S, I, and I2 treatments at SC-1, and 46.8, 37.6, and 204.6 $\mathrm{Mg} \mathrm{ha}^{-1}$ at SC-2 (Sanchez et al., 2003). After tillage, dolomite lime was applied at a rate of $3.4 \mathrm{Mg} \mathrm{ha}^{-1}$ and disked into the soil to achieve a target soil $\mathrm{pH}$ of 6.5 .

\subsection{Sample collection and analyses}

Soil samples were collected in April 2005 at the California sites (0-15 cm depth), and in June 2005 at the South Carolina sites (0$30 \mathrm{~cm}$ depth). Depth of sampling varied between regional studies 
based on the effective depth of the incorporation treatments. Six to eight samples were collected per plot along two, systematically located transect lines. Soils were collected using a $7.3 \mathrm{~cm}$-diameter corer at the California sites to ensure inclusion of large organic fragments. A smaller corer ( $2.5 \mathrm{~cm}$-diameter) was used at the South Carolina sites since large organics were not discernible in the mineral soil at the time of sampling. Soil cores were combined into one composite sample per plot. Samples from the California sites were transported on the day of collection to our laboratory facility in Redding, CA, while samples from South Carolina were delivered to the Redding laboratory within $72 \mathrm{~h}$ of collection.

Soil from the California sites was separated by sieving and hand sorting into fine $(<2 \mathrm{~mm})$, coarse organic $(>2 \mathrm{~mm})$, and rock $(>2 \mathrm{~mm}$ ) fractions. Gravimetric moisture content was determined using subsamples from each fraction, and the relative dry-weight proportion of each was calculated. The rock fraction was then discarded. Soil from the South Carolina sites was sieved $(2 \mathrm{~mm})$, and the fine fraction retained. De-ionized water was added to bring the fine-fraction samples to $60 \%$ water-filled pore space. No additional water was needed for the coarse-fraction samples. All samples were then covered and incubated at room temperature for a minimum of $11 \mathrm{~d}$ prior to analyses to subside spurious microbial activity associated with sampling disturbance. This incubation period was determined in preliminary experiments as a minimum before $\mathrm{CO}_{2}$ production declined to steady state (basal respiration). Thus, all analyses should be considered measures of soil potential and may not reflect conditions at the time of sampling.

All samples were analyzed for total C (Carlo Erba C/N/S analyzer, Fisons Instruments, Danvers, MA), microbial biomass (substrateinduced respiration), basal respiration, fungal hyphal biomass, and bacterial biomass. Microbial biomass and basal respiration were determined using $25 \mathrm{~g}$ of mineral soil (dry-weight equivalent) or 1$2 \mathrm{~g}$ of large organics (dry-weight equivalent). Optimal glucose concentrations for microbial biomass $\left(5 \mathrm{~g} \mathrm{~kg}^{-1}\right.$ for soil and $0.3 \mathrm{~g} \mathrm{~kg}^{-1}$ for organics) were determined in preliminary tests, and $\mathrm{CO}_{2}$ production was analyzed 1-2 $\mathrm{h}$ after the addition of glucose. Basal respiration was determined as the amount of accumulated $\mathrm{CO}_{2}$ during a $24 \mathrm{~h}$ period without added glucose.

Fungal biomass was estimated by fluorescent microscopy using fluorescent brightener 28 (FB28; Sigma-Aldrich, St. Louis, MI) to determine total hyphal biovolume and fluorescein diacetate (FDA) to determine active hyphal biovolume (Söderström, 1977; Ingham and Klein, 1982, 1984). Hyphae were extracted from soil by agitating $10 \mathrm{~g}$ (dry wt. equivalent) soil in $95 \mathrm{ml}$ dilute Ringers solution (2.25 g NaCl, $0.11 \mathrm{~g} \mathrm{KCl}, 0.12 \mathrm{~g} \mathrm{CaCl}_{2}, 0.05 \mathrm{~g} \mathrm{NaHCO}_{3}$, and 1.0 L filter-sterilized- $\mathrm{H}_{2} \mathrm{O}$ ) for $10 \mathrm{~min}$ using a wrist-action shaker. Following shaking, the samples were diluted in $0.3 \mathrm{M}$ phosphate buffer to a final dilution of $1 \mathrm{mg}$ soil ml $\mathrm{m}^{-1}$. Hyphae were extracted from organic samples (1-3 g dry wt. equivalent) in $100 \mathrm{ml}$ Ringer's solution using a high speed Waring blender for $1 \mathrm{~min}$. This was determined in a preliminary experiment as the optimal recovery time for hyphae, in agreement with previous reports (Söderström, 1979; West, 1988). The organic samples were then diluted with $0.3 \mathrm{M}$ phosphate buffer to a final dilution of $1.5 \mathrm{mg} \mathrm{ml}^{-1}$.

All diluted samples $(1 \mathrm{ml})$ were stained with $0.5 \mathrm{ml} \mathrm{FB} 28$ ( $0.002 \mathrm{mg} \mathrm{ml}^{-1}$ filter-sterilized $\mathrm{H}_{2} \mathrm{O}$ clarified with $1 \mathrm{M} \mathrm{NaOH}$ ) for $30 \mathrm{~min}$. at room temperature in the dark. Following staining, the samples were filtered onto $0.2 \mu \mathrm{m}$ blackened Millipore filters, and viewed using a Zeiss Axioscop fluorescent microscope at $400 \times$ magnification with a 01 filter set. Hyphal lengths and widths were measured on 20 fields per sample, and converted to biomass using the method of Bottomley (1994). For active fungal biomass, diluted samples $(1 \mathrm{ml})$ were stained for $3 \mathrm{~min}$ with $20 \mu \mathrm{FDA}\left(2 \mathrm{mg} \mathrm{ml}^{-1}\right.$ acetone). Stained samples were then filtered onto $0.2 \mathrm{~mm}$ blackened polycarbonate filters, and viewed at $400 \times$ magnification using Zeiss filter set 09 .
Bacteria were stained with SYBR Green I (Invitrogen Corp., Carlsbad, CA) to measure total cell volume, and with propidium iodide to measure membrane-compromised cells (Williams et al., 1998; Luna et al., 2002). Soil extractions were made on the same day and followed the same methods as those for determining fungal biomass. The samples were frozen $\left(-20^{\circ} \mathrm{C}\right)$ for two weeks before microscope analyses, while the fungal samples were being quantified by epifluorescence. Preliminary tests showed no significant change in bacterial number or biomass resulted due to freezing. Following thawing at room temperature, the samples ( $1 \mathrm{ml}$ ) were filtered onto $0.02 \mu \mathrm{m}$ Whatman anodisc filters using $<80 \mathrm{~mm}$ Hg pressure (Kepner and Pratt, 1994). Each filter was then double-stained with $15 \mu \mathrm{l}$ SYBR Green I $\left(10^{-3}\right.$ dilution in filtersterilized $\left.\mathrm{H}_{2} \mathrm{O}\right)$ and $15 \mu \mathrm{l}$ propidium iodide $\left(0.1 \mu \mathrm{g} \mu \mathrm{l}^{-1}\right.$ filter-sterilized $\mathrm{H}_{2} \mathrm{O}$ ) as described by Noble and Fuhrman (1998). Filters were incubated in the dark for $15 \mathrm{~min}$, and viewed using a Zeiss filter set 09 for SYBR Green and filter set 15 for propidium iodide. Cell numbers and diameters were measured on 10 fields per sample for each stain, averaging 20-50 cells per field. Total biomass was calculated using the method outlined by Bottomley (1994). Active bacteria were calculated by subtracting propidium iodide biomass (compromised cells) from total bacterial biomass.

\subsection{Statistical analyses}

The effects of residue treatment and site location on soil properties were tested by two-way ANOVA using PROC MIXED (SAS) with a "variance component" covariate structure. Separate analyses were made for the California and South Carolina datasets since the treatments and sampling depths differed between the studies. Data were log or square-root transformed, as necessary, to account for unequal variances, and then backtransformed following statistical analyses for presentation purposes. Bonferroni's adjusted means comparison test was used to compare treatment means within a site. Statistical significance was considered at $\alpha=0.10$.

\section{Results}

\subsection{Coarse fraction $C$}

Coarse fraction $\mathrm{C}$ ( $>2 \mathrm{~mm}$ organics) was inconspicuous in the South Carolina samples, reflecting both the warm, moist climate for decay and the length of time since incorporation. We collected samples in the 6th year after treatment at the South Carolina sites, compared to the 4th and 2nd years after treatment at CA-1 and CA-2, respectively. In comparison, coarse fraction $\mathrm{C}$ comprised 3-6\% of the soil mass in the incorporated treatment at the California sites (Table 1 ). This equated to $9-15 \%$ of the total soil volume, calculated using site bulk density values of $0.32 \mathrm{~g} \mathrm{~cm}^{-3}$ for coarse fractions and $0.85 \mathrm{~g} \mathrm{~cm}^{-3}$ for the whole soil (Busse, data on file). Differences in coarse fraction $C$ between incorporated and surface-applied treatments were significant at CA-2 only.

\section{Table 1}

Large organic residue content $\left(\mathrm{g} \mathrm{kg}^{-1}\right)$ at a depth of $0-15 \mathrm{~cm}$ in the mineral soil at the California sites. Understory trees and woody shrubs were either left intact (NT); masticated and left on the soil surface (S); or masticated and incorporated (I). Means within a column followed by different letters are significantly different by Bonferroni's adjusted means comparison.

\begin{tabular}{llc}
\hline Residue treatment & CA-1 & CA-2 \\
\hline NT & $31.3 \mathrm{~b}$ & $13.5 \mathrm{~b}$ \\
S & $47.0 \mathrm{ab}$ & $12.0 \mathrm{~b}$ \\
I & $60.5 \mathrm{a}$ & $34.3 \mathrm{a}$ \\
Common s.e. & 7.3 & 7.3 \\
\hline
\end{tabular}




\subsection{Soil C}

Total soil C (fine and coarse fraction C) was 8-fold higher on average at the California sites than the South Carolina sites (Fig. 1). Treatment differences also varied by region. Incorporated residues resulted in significantly lower soil $C$ compared to surface-applied residues at both South Carolina sites, whereas the opposite trend was found in California. Even increasing the mass of incorporated residues (I2) to $67 \mathrm{Mg} \mathrm{ha}^{-1}$ at SC-1 or $204 \mathrm{Mg} \mathrm{ha}^{-1}$ at SC-2 did not produce a sizeable change in soil $\mathrm{C}$ relative to native slash levels (I). Microbial biomass $\mathrm{C}$ followed a similar trend as total soil $\mathrm{C}$, increasing slightly due to residue incorporation in California and decreasing in South Carolina. No differences in the metabolic quotient $\left(q \mathrm{CO}_{2}\right)$ were found between the surface and incorporated residue treatments, as soil respiration was proportional to microbial $C$ at each site. Only the non-treated plots at CA-2 had a higher $q \mathrm{CO}_{2}$ compared to the residue treatments.

\subsection{Fungal and bacterial biomass}

Fungal biomass was generally unaffected by incorporating masticated residues at the California sites. No differences in active or total fungal biomass were found between the $\mathrm{S}$ and I treatments in the fine or coarse fractions, with the exception of lower active biomass in the coarse fraction following residue incorporation at CA-1 (Fig. 2). Two additional observations were of note. First, active fungal biomass was low for all treatments, ranging from 1 to $20 \%$ of the total fungal biomass. Second, coarse fraction organics comprised nearly $50 \%$ of the total fungal biomass of S and I treatments at CA-1. Untreated plots had the highest fungal biomass in mineral soil at CA-1 and the lowest fungal biomass in coarse fraction organics. This likely reflected the unique stand conditions (extremely dense layer of understory vegetation) and the low mass of coarse fraction $C$ in the NT plots.

Active and total bacterial biomass in the mineral soil were substantially greater for I compared to either S or NT plots at CA-1 (Fig. 3). No differences in bacterial biomass were found among treatments at CA-2, however. The majority of the bacterial biomass at the California sites was active and found in the mineral soil fraction. The active $\mathrm{F}: \mathrm{B}$ ratio was $0.29 \pm 0.09$ (s.e.) at $\mathrm{CA}-1$ and $0.25 \pm 0.09$ at CA-2, with no significant treatment differences at either site.

Few treatment differences in fungal or bacterial biomass were found at the South Carolina sites. Residue additions of $67 \mathrm{Mg} \mathrm{ha}^{-1}$ (I2) resulted in higher fungal biomass than surface-applied residues at SC- 1 only, while additions of $207 \mathrm{Mg} \mathrm{ha}^{-1}$ resulted in the greatest active bacterial biomass at SC-2 (Fig. 4). Similar to the response at the California sites, active fungal biomass was generally under $10 \%$ of the total fungal biomass, while a larger proportion of the bacterial biomass was active. The active $\mathrm{F}: \mathrm{B}$ ratio was $0.34 \pm 0.10$ at SC- 1 and $0.49 \pm 0.09$ at SC-2, with no significant treatment differences at either site. No differences in total F:B biomass ratios were detected among residue treatments at the four sites (Fig. 5). Site differences were considerable, however, ranging from 1.1 to 5.0.

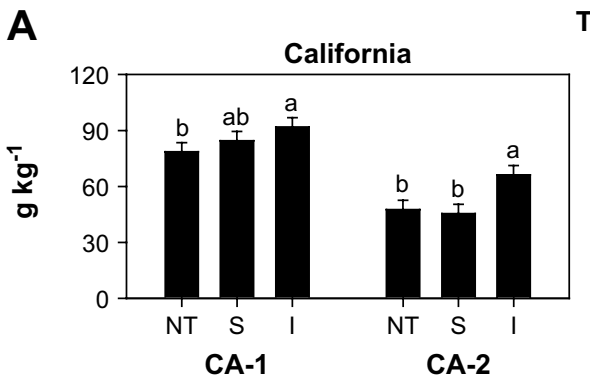

Total soil C

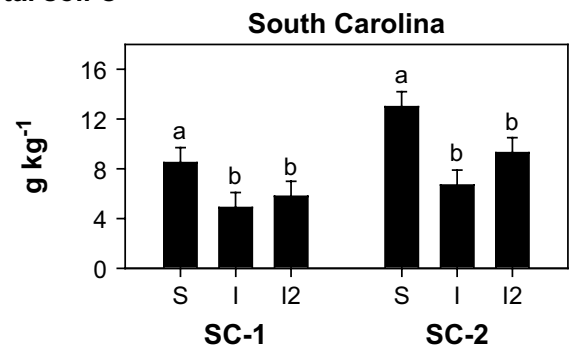

B

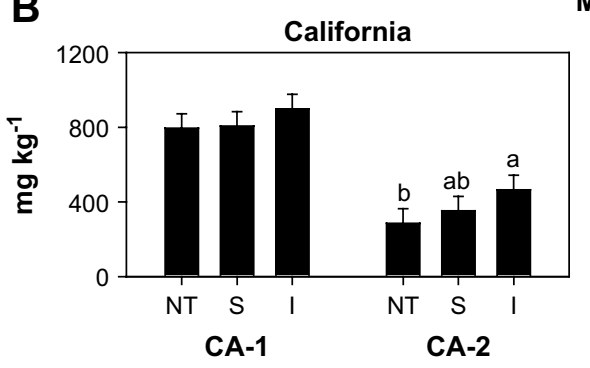

Microbial C

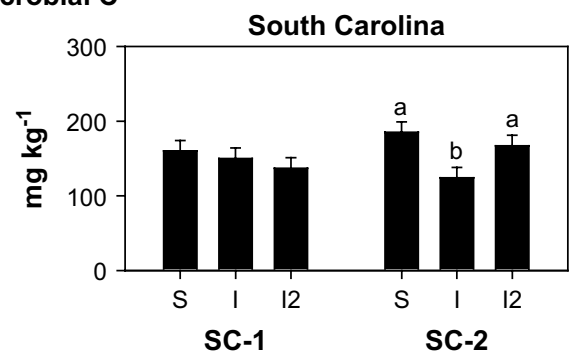

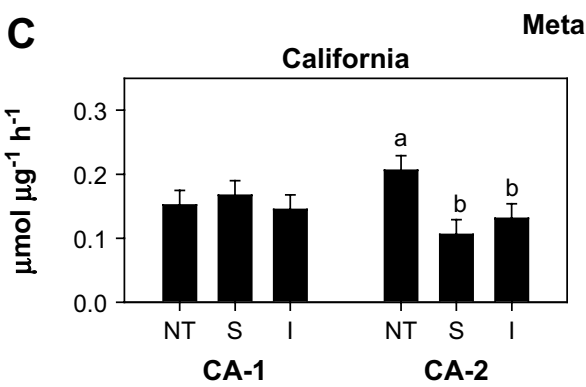

Metabolic quotient

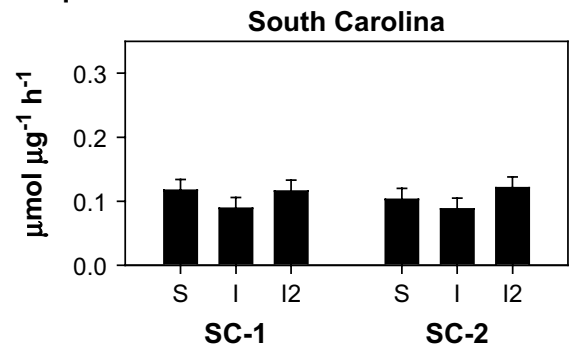

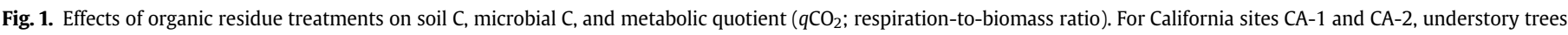

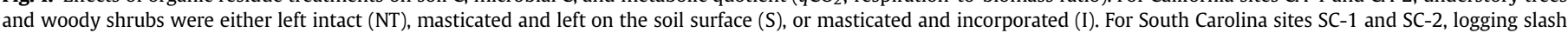

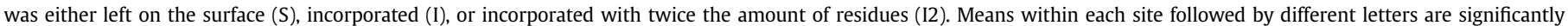
different by Bonferroni's adjusted means comparison $(\alpha=0.10)$. Error bars represent s.e. 

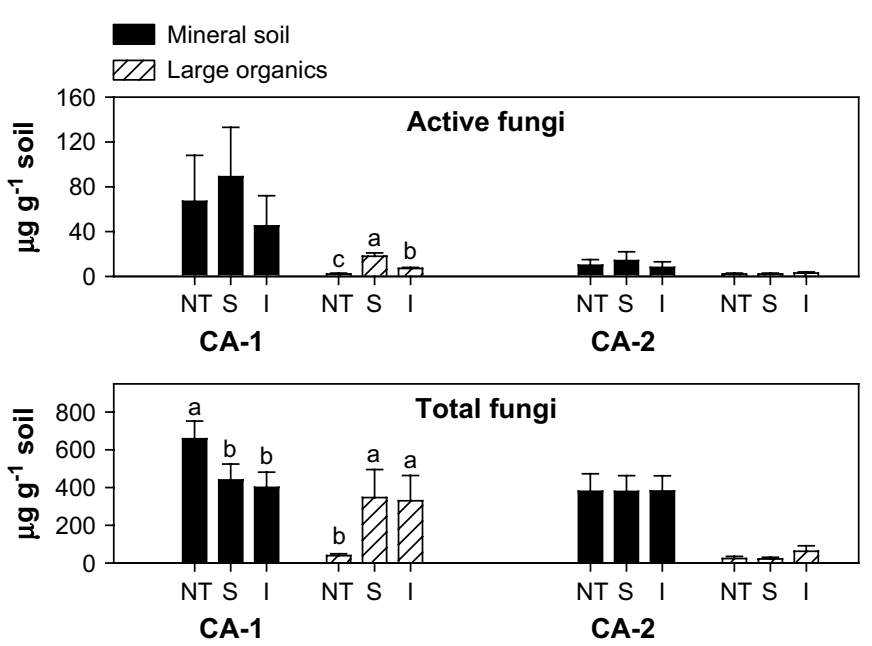

Fig. 2. Fungal biomass in the large organic $(>2 \mathrm{~mm})$ and mineral soil $(<2 \mathrm{~mm})$ fractions at a depth of $0-15 \mathrm{~cm}$ in the mineral soil at California sites CA- 1 and CA-2. Understory trees and woody shrubs were either left intact (NT), masticated and left on the soil surface $(S)$, or masticated and incorporated (I). Active biomass was measured using FDA stain, and total biomass was measured using calcofluor-FB28 brightener. Means within a site followed by different letters are significantly different by Bonferroni's adjusted means comparison $(\alpha=0.10)$. Error bars represent s.e.

\section{Discussion}

\subsection{Coarse fraction $C$}

Most studies investigating management impacts on total soil $\mathrm{C}$ only utilize the fine fraction $\mathrm{C}(<2 \mathrm{~mm})$ and ignore coarse fraction $\mathrm{C}$ ( $>2 \mathrm{~mm}$ organics). A justification for this practice is that the coarse fraction C is generally very labile (Cambardella and Elliott, 1992; Sollins et al., 1996) and consequently does not represent a longterm $\mathrm{C}$ pool. This reasoning may be valid at sites with rapid decomposition rates, such as the South Carolina sites in this study, where the coarse fraction $C$ is rapidly lost and constitutes a very small fraction of the total soil $\mathrm{C}$ pool. However, in sites with slow decomposition rates, coarse fraction $\mathrm{C}$ may persist and may constitute a sizable component of the total soil $\mathrm{C}$ pool. This was apparent in our study, particularly at CA-1. Here, the coarse fraction
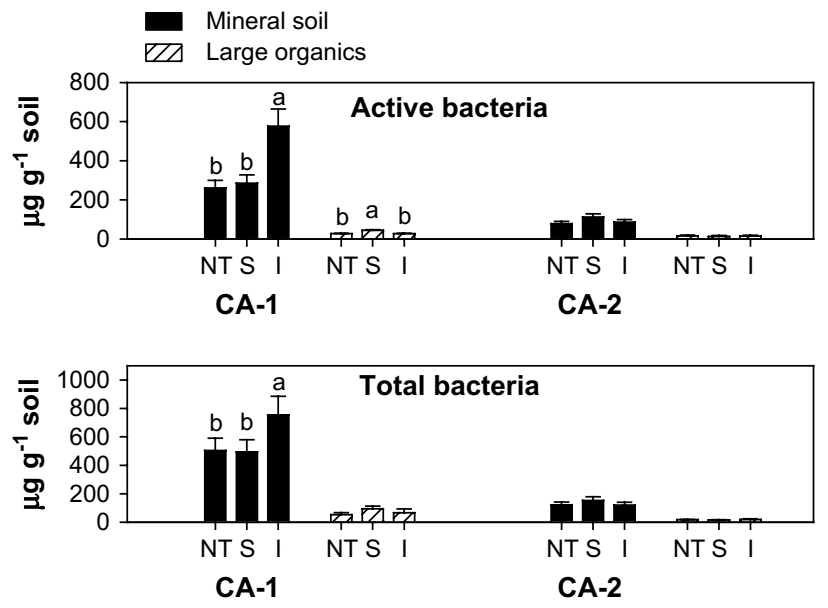

Fig. 3. Bacterial biomass in the large organic $(>2 \mathrm{~mm})$ and mineral soil $(<2 \mathrm{~mm})$ fractions at a depth of $0-15 \mathrm{~cm}$ in the mineral soil at California sites CA-1 and CA-2. Understory trees and woody shrubs were either left intact (NT), masticated and left on the soil surface $(S)$, or masticated and incorporated (I). Active biomass was measured using propidium iodide and total biomass was measured using SYBR Green stain. Means within a site followed by different letters are significantly different by Bonferroni's adjusted means comparison $(\alpha=0.10)$. Error bars represent s.e.
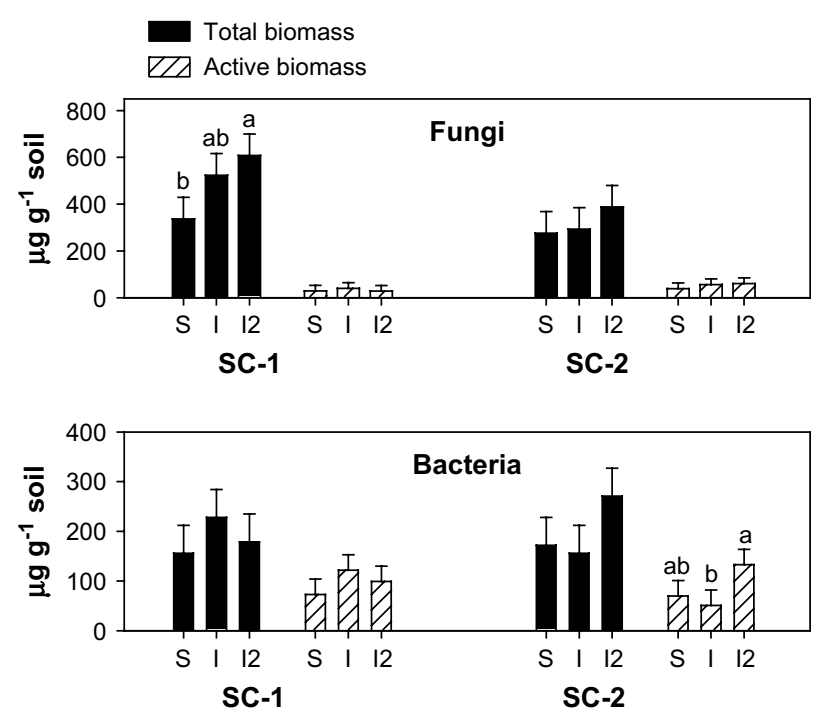

Fig. 4. Fungal and bacterial biomass at South Carolina sites SC-1 and SC-2, separated into active and total biomass. Logging slash was chipped and either left on the soil surface (S), incorporated (I), or incorporated with twice the amount of chips (I2). Means within a site followed by different letters are significantly different by Bonferroni's adjusted means comparison $(\alpha=0.10)$. Error bars are s.e.

C contributed nearly one-third of the total soil C (data not shown) and one-half of the total fungal biomass on residue-incorporation plots. Coarse fraction $\mathrm{C}$ also contributed about one-fourth of the total soil $\mathrm{C}$ pool at CA-2, even though the input of masticated residues was substantially lower at CA-2 than any other site. Thus, omitting coarse fraction $C$ during soil $C$ analyses may result in incomplete or inaccurate results, and should be reconsidered on a case-by-case basis.

\subsection{Soil C}

Most models on soil organic matter dynamics, including the CO2FIX model used by Buford and Stokes (2000), assume decomposition follows first-order kinetics and that a linear relationship exists between soil C content and C input (Six et al., 2002). A consequence of this assumption is that soil $\mathrm{C}$ can increase indefinitely so long as there is a continual $C$ source. The presumed lack of a $\mathrm{C}$ saturation point for soils is not realistic. Some long-term agricultural studies on soils with high initial $\mathrm{C}$ contents have shown little or no increase in soil C despite considerable increases in C inputs (Campbell et al., 1991; Paustian et al., 1997; Solberg et al., 1997). In a forestry example, Sanchez and Bursey (2002) found that soil $\mathrm{C}$ concentrations adjacent to first-order root systems of 40 -year-old loblolly pines were $55 \%$ greater than the soil $\mathrm{C}$ concentrations away from major root systems. They attributed the increase in soil $C$ to the continual input of dead fine roots and root exudates. However, ${ }^{13} \mathrm{C}$ nuclear magnetic resonance analysis of the soil extracts indicated that the additional $\mathrm{C}$ around root systems was highly labile and transient in nature (Sanchez and Bursey, 2002).

Some models have been developed that include a $\mathrm{C}$ saturation point for soils that is intimately tied to the silt and clay content of the soil (Hassink and Whitmore, 1997; Six et al., 2002). However, the contribution of clays (and presumably silt) in stabilizing $C$ decreases with weathering (Torn et al., 1997). Additionally, the influence of climate on decomposition and C stabilization cannot be ignored. Sites with rapid decomposition rates, such as the South Carolina sites in this study, are further limited in their potential to stabilize C (Six et al., 2002). These findings suggest that weathered soils in climates that favor rapid decomposition of organic matter 

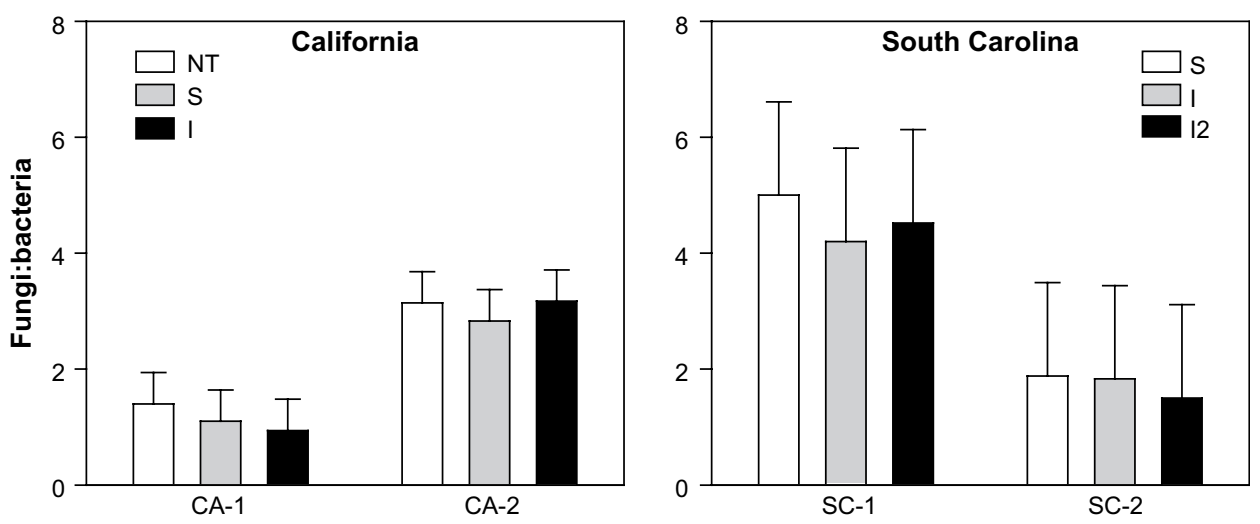

Fig. 5. Response of fungal:bacterial biomass ratio to organic residue treatments at contrasting sites in California and South Carolina. Error bars are s.e.

would have a low $\mathrm{C}$ saturation point and would thus be limited in their potential to sequester $\mathrm{C}$. This hypothesis is consistent with the observations of $\mathrm{C}$ stabilization at the California and South Carolina sites. In the South Carolina sites, soil C decreased with incorporation of organic matter despite the large amount of residue added, especially in the I 2 treatment (Fig. 1). This effect was consistent for the sandy and clayey sites indicating that the clay content did not effectively stabilize $C$ at these sites. The observed loss of soil $C$ was probably a consequence of the action of tillage which promotes oxidation of previously protected soil C (Balesdent et al., 2000). These observations do not necessarily mean that the South Carolina sites have reached their $C$ saturation point. Hassink and Whitmore (1997) estimated that approximately $21 \%$ of a soil's protective capacity (e.g. C saturation point) was influenced by factors other than clay and silt content. Soil $\mathrm{C}$ can be stabilized by other mechanisms including physical (aggregation, inclusion into small pore volumes) and biochemical (proportion of recalcitrant compounds such as lignin) protection (Balesdent et al., 2000; Six et al., 2002). Experiments that assess aggregate formation and the effects of substrate quality (e.g. lignin content) may provide insight as to the potential of these sites to sequester $C$. In California, the combination of a cool/dry climate and higher activity clays resulted in $C$ being stabilized into the soil despite the degradative effects of tillage (Fig. 1). Consequently, this study suggests that land management efforts that include forest slash incorporation may have a greater potential to sequester $C$ in sites where the climate moderates decomposition and the soil includes less weathered clay material. Continued assessment of the California sites is needed, however, to clarify whether the stabilization of organic residues is short- or long-lived.

\subsection{Fungal and bacterial biomass}

Our hypothesis that the incorporation of woody residues would preferentially stimulate soil fungal biomass was not supported at the four study sites. We found no increases in F:B ratios among treatments, while the only absolute increase in total fungal biomass was found at SC-1 for the $67 \mathrm{Mg} \mathrm{ha}^{-1}$ residue-incorporation treatment. Instead, the residues treatments had an inconsistent effect on coarse-scale microbial community structure. This is somewhat surprising since the amount of added organics, which ranged from 20 to $75 \mathrm{Mg} \mathrm{ha}^{-1}$ in California and from 32 to $205 \mathrm{Mg} \mathrm{ha}^{-1}$ in South Carolina, was not trivial and likely represented the upper range of practicable residue additions in managed forests. The reason for this modest response is not clear, yet presumably reflects the physical and chemical properties of the large masticated residues (low surface area-to-volume ratio; low nutrient content; and high lignin content).
Fungal:bacterial ratios determined using an assortment of analytical methods typically range from 1.0 to 2.0 in forest mineral soil (Scheu and Parkinson, 1994; Alphei et al., 1995; Bailey et al., 2002; Ananyeva et al., 2006), although higher values have been measured in acidic soils (Blogodatskaya and Anderson, 1998; Bååth and Anderson, 2003). Results from our study sites show a wider range in F:B ratio than previously reported for forested sites. Morris and Boerner (1999) reported that $F: B$ ratios varied depending on spatial scale in eastern USA hardwood forests. They found that F:B ratios were relatively constant within watersheds and individual forest stands, but differed considerably between geographically isolated sites. Our findings are in agreement with those of Morris and Boerner (1999). Within-site differences were minor, while a five-fold range in values existed among the four isolated sites. Interestingly, the soils with the lowest F: $\mathrm{B}$ ratio (CA-1, SC-2) had the highest total $C$ content in their respective regions, which is counter to concept that the $\mathrm{F}: \mathrm{B}$ ratio increases with increasing soil organic matter content (Bailey et al., 2002). In addition, we saw no trend in the $\mathrm{F}: \mathrm{B}$ ratio as a function of soil texture, as the ratio was the lowest in the clayey soil in California and the highest in the clayey soil in South Carolina.

The microbial metabolic quotient (respiration-to-biomass ratio; $\left.q \mathrm{CO}_{2}\right)$, an indicator of the C-use efficiency of the microbial community, was similar among the residue treatments at each site. This result compliments our findings for F:B community structure and supports the apparent insensitivity of the microbial community to woody-residue incorporation. Differences in $\mathrm{qCO}_{2}$ among the four sites were also generally small (Fig. 1) despite considerable site differences in soil quality characteristics (total C content, microbial $\mathrm{C}$ biomass, clay content, and $\mathrm{pH}$ ) and climate. Whether the similarities in $q \mathrm{CO}_{2}$, both within and between sites, are a simple reflection of the common vegetation type (young conifer plantations) and its influence on soil organic matter quality, or whether they reflect the insensitivity of the $q \mathrm{CO}_{2}$ measurement to depict ecosystem development (Wardle and Ghani, 1995) is unclear. Further assessments of microbial C-use efficiency across diverse ecosystem types and climates are needed to help improve our understanding of microbial regulation of soil $\mathrm{C}$ sequestration.

No clear trend in active fungal or active bacterial biomass was found among treatments at the four sites. Similar to results from other studies (Söderström, 1979; Klein and Paschke, 2000), active fungi comprised only a small fraction of the total fungal biomass. Whether this reflected the true physiological state of the soil hyphae and their ability to produce cytoplasm-free, "ghost" hyphae (Klein et al., 1995), or was an underestimation of hyphal activity by the FDA-staining method (Söderström, 1979) is unknown. Still, the similarity in treatment response between active and total fungi, regardless of their absolute values, substantiates the general 
indifference by fungal hyphae to the residue treatments. Unlike fungal biomass, the majority of bacterial biomass was found to be active in these soils. Active bacterial biomass was two- to fourtimes greater than active fungal biomass across all sites. Again, this may reflect the optimal soil moisture and temperature conditions for bacterial activity during sample incubation, or it may be a consequence of the propidium-iodide staining method, which measures bacterial cell-wall integrity but not necessarily metabolic activity (Williams et al., 1998).

Some caution is also recommended when comparing results for fungal biomass, bacterial biomass, and F:B ratio among published studies. Common methods currently reported in literature include fluorescent microscopy (Bottomley, 1994); selective inhibition of glucose-amended soil (Anderson and Domsch, 1973); and phospholipid fatty acid analysis (PLFA; Frostegård and Bååth, 1996). While each method has its strength, each is a distinct measure of biomass that does not necessarily agree quantitatively with the others (Velvis, 1997; Bailey et al., 2002; Bååth and Anderson, 2003). For example, PLFA provides a coarse-scale, comparative measure of fungi and bacteria diversity based on soil lipid fractionation, but it does not directly assess total biomass, while the selective-inhibition method is a measure of the glucose-active fungal and bacterial biomass. In comparison, fluorescent microscopy provides a true measure of hyphal and bacterial biovolume which can be separated into total and active biomass using complementary stains. Thus, any comparison of fungal and bacterial biomass between these methods should be limited to the identification of broadscale treatment responses, while avoiding comparisons of absolute biomass quantities.

\section{Conclusions}

We assessed changes in microbial community structure and $C$ dynamics in response to surface-applied and soil-incorporated woody residues in western and southeastern USA forest soils. High levels of residue incorporation generally had little effect on fungal biomass, bacterial biomass, $\mathrm{F}: \mathrm{B}$ ratios, or $q \mathrm{CO}_{2}$, likely due to the large fragment size of the added organics (California sites) or the rapid decay of the residues (South Carolina sites). Short-term changes in total soil $\mathrm{C}$ were noted, although they varied by region. A decline in soil $\mathrm{C}$ was found in the sixth year after residue incorporation in South Carolina, presumably due to the ideal climatic conditions for decomposition, the dominant clay mineralogy (inactive 1:1 kaolinite), and the disturbance effects of tillage on soil physiochemical properties. In contrast, soil $\mathrm{C}$ was somewhat greater in the California soils two to four years after residue incorporation. However, we question the potential for long-term soil $\mathrm{C}$ accrual following residue incorporation in these forest soils given the variable effect on soil $\mathrm{C}$ pools and the inconsequential effect on fungal or bacterial biomass.

\section{Acknowledgements}

Support was provided by the Department of Energy-Savannah River Operations Office through the U.S. Forest Service Savannah River, by the Department of Energy's Office of Science, Biological and Environmental Research funding to the Consortium for Research on Enhancing Carbon Sequestration in Terrestrial Ecosystems (CSiTE), and by the U.S. National Fire Plan.

\section{References}

Alphei, J., Bonkowski, M., Scheu, S., 1995. Application of the selective inhibition method to determine bacterial:fungal ratios in three beechwood soils rich in carbon - optimization of inhibitor concentrations. Biology and Fertility of Soils 19, 173-176.
Ananyeva, N.D., Susyan, E.A., Chernova, O.V., Chernov, I.Y., Makarova, O.L., 2006. The ratio of fungi and bacteria in the biomass of different types of soil determined by selective inhibition. Microbiology 75, 702-707.

Anderson, J.P.E., Domsch, K.H., 1973. Quantification of bacterial and fungal contribution to soil respiration. Archives of Microbiology 93, 113-127.

Bååth, E., Anderson, T.-H., 2003. Comparison of soil fungal/bacterial ratios in a $\mathrm{pH}$ gradient using physiological and PLFA-based techniques. Soil Biology \& Biochemistry 35, 955-963.

Bailey, V.L., Smith, J.L., Bolton Jr., H., 2002. Fungal-to-bacterial ratios in soils investigated for enhanced C sequestration. Soil Biology \& Biochemistry 34, 997-1007.

Balesdent, J., Chenu, C., Balabane, M., 2000. Relationship of soil organic matter dynamics to physical protection and tillage. Soil \& Tillage Research 53, 215-230.

Bardgett, R.D., Hobbs, P.J., Frostegård, A., 1996. Changes in soil fungal:bacterial biomass ratios following reduction in the intensity of management of an upland grassland. Biology and Fertility of Soils 22, 261-264.

Blogodatskaya, E.V., Anderson, T.-H., 1998. Interactive effects of $\mathrm{pH}$ and substrate quality on the fungal-to-bacterial ratio and $\mathrm{QCO}_{2}$ of microbial communities in forest soils. Soil Biology \& Biochemistry 30, 1269-1274.

Bossuyt, H., Denef, K., Six, J., Frey, S.D., Merckx, R., Paustian, K., 2001. Influence of microbial populations and residue quality on aggregate stability. Applied Soil Ecology 16, 195-208.

Bottomley, P.J., 1994. Light microscopic methods for studying soil microorganisms. In: Weaver, R.W. (Ed.), Methods of Soil Analysis. Part 2. Microbiological and Biochemical Properties. Soil Science Society of America, Madison, WI, pp. 81-105.

Brant, J.B., Sulzman, E.W., Myrold, D.D., 2006. Microbial community utilization of added carbon substrates in response to long-term carbon input manipulation. Soil Biology \& Biochemistry 38, 2219-2232.

Buford, M.A., Stokes, B.J., 2000. Incorporation of biomass into forest soils for enhanced productivity, restoration, and biostorage: a modelling study to evaluate research needs. New Zealand Journal of Forestry Science 30, 130-137.

Cambardella, C.A., Elliott, E.T., 1992. Particulate soil organic matter across a grassland cultivation sequence. Soil Science Society of America Journal 56, 777-783.

Campbell, C.A., Bowren, K.E., Schnitzer, M., Zentner, R.P., Townley-Smith, L., 1991. Effect of crop rotations and fertilization on soil biochemical properties in a thick Black Chernozem. Canadian Journal of Soil Science 71, 377-387.

de Vries, F.T., Hoffland, E., van Eekeren, N., Brussaard, L., Bloem, J., 2006. Fungal/ bacterial ratios in grasslands with contrasting nitrogen management. Soil Biology \& Biochemistry 38, 2092-2103.

Doran, J.W., Parkin, T.B., 1994. Defining and assessing soil quality. In: Doran, J.W. (Ed.), Defining Soil Quality for a Sustainable Environment. Soil Science Society of America Special Publication No. 35. Soil Science Society of America, Madison, WI, USA, pp. 3-21.

Frey, S.D., Elliott, E.T., Paustian, K., 1999. Bacterial and fungal abundance and biomass in conventional and no-tillage agroecosystems along two climatic gradients. Soil Biology \& Biochemistry 31, 573-585.

Frey, S.D., Knorr, M., Parrent, J., Simpson, R.T., 2004. Chronic nitrogen enrichment affects the structure and function of the soil microbial community in a forest ecosystem. Forest Ecology and Management 196, 159-171.

Frostegård, A., Bååth, E., 1996. The use of phospholipid fatty acid analysis to estimate bacterial and fungal biomass in soil. Biology and Fertility of Soils 22, 59-65.

Grigal, D.F., 2000. Effects of extensive forest management on soil productivity. Forest Ecology and Management 138, 167-185.

Hassink, J., Whitmore, A.P., 1997. A model of the physical protection of organic matter in soils. Soil Science Society of America Journal 61, 131-139.

Heath, L.S., Kimble, J.M., Birdsey, R.A., Lal, R., 2003. The potential of U.S. forest soils to sequester carbon. In: Kimble, J.M. (Ed.), The Potential of U.S. Forest Soils to Sequester Carbon and Mitigate the Greenhouse Effect. CRC Press, New York, pp. 385-394.

Högberg, M.N., Chen, Y., Högberg, P., 2007. Gross nitrogen mineralisation and fungito-bacteria ratios are negatively correlated in boreal forests. Biology and Fertility of Soils 44, 363-366.

Ingham, E.R., Klein, D.A., 1982. Relationship between fluorescein diacetate-stained hyphae and oxygen utilization, glucose utilization, and biomass of submerged fungal batch cultures. Applied and Environmental Microbiology 4, 363-370.

Ingham, E.R., Klein, D.A., 1984. Soil fungi: relationships between hyphal activity and staining with fluorescein diacetate. Soil Biology \& Biochemistry 16, 273-278.

Jenny, H., 1994. Factors of Soil Formation. A System of Quantitative Pedology. Dover Press, New York.

Johnson, D.W., Curtis, P.S., 2001. Effects of forest management on soil C and $\mathrm{N}$ storage: meta analysis. Forest Ecology and Management 140, 227-238.

Jurgensen, M.F., Harvey, A.E., Graham, R.T., Page-Dumroese, D.S., Tonn, J.R., Larsen, M.J., Jain, T.B., 1997. Impacts of timber harvesting on soil organic matter, nitrogen, productivity, and health of Inland Northwest forests. Forest Science 43, 234-251.

Kepner, R.L., Pratt, J.R., 1994. Use of fluorochromes for direct enumeration of total bacteria in environmental samples: past and present. Microbiological Reviews 58, 603-615.

Kimble, J.M., Heath, L.S., Birdsey, R.A., Lal, R., 2003. The Potential of U.S. Forest Soils to Sequester Carbon and Mitigate the Greenhouse Effect. CRC Press, New York

Klein, D.A., Paschke, M.W., 2000. A soil microbial community structural-functional index: the microscopy-based total/active/active fungal/bacterial (TA/AFB) biovolumes ratio. Applied Soil Ecology 14, 257-268.

Klein, D.A., McLendon, T., Paschke, M.W., Redente, E.F., 1995. Saprophytic fungalbacterial biomass variations in successional communities of a semi-arid steppe ecosystem. Biology and Fertility of Soils 19, 253-256. 
Lal, R., 2001. The potential of soil carbon sequestration in forest ecosystems to mitigate the greenhouse effect. In: Lal, R. (Ed.), Soil Carbon Sequestration and the Greenhouse Effect. Soil Science Society of America Special Publication 57. Soil Science Society of America, Madison, WI.

Luna, G.M., Manini, E., Danovaro, R., 2002. Large fraction of dead and inactive bacteria in coastal marine sediments: comparison of protocols for determination and ecological significance. Applied and Environmental Microbiology 68, 3509-3513.

Morris, S.J., Boerner, R.E.J., 1999. Spatial distribution of fungal and bacterial biomass in southern Ohio hardwood forest soils: scale dependency and landscape patterns. Soil Biology \& Biochemistry 31, 887-902.

Nambiar, E.K.S., 1997. Sustained productivity of forests as a continuing challenge to soil science. Soil Science Society of America Journal 60, 1629-1642.

Noble, R.T., Fuhrman, J.A., 1998. Use of SYBR Green I for rapid epifluorescence counts of marine viruses and bacteria. Aquatic Microbial Ecology 14, 113-118.

Paul, K.I., Polglase, P.J., Nyakuengama, J.G., Khanna, P.K., 2002. Change in soil carbon following afforestation. Forest Ecology and Management 168, 241-257.

Paustian, K., Collins, H.P., Paul, E.A., 1997. Management controls on soil carbon. In: Paul, E.A., Paustian, K., Elliott, E.T., Cole, C.V. (Eds.), Soil Organic Matter in Temperate Agroecosystems. CRC Press, Boca Raton, FL, pp. 15-49.

Ratcliff, A.W., Busse, M.D., Shestak, C.J., 2006. Changes in microbial community structure following herbicide (glyphosate) additions to forest soils. Applied Soil Ecology 34, 114-124.

Richter, D.D., Markewitz, D., Trumbore, S.E., Wells, C.G., 1999. Rapid accumulation and turnover of soil carbon in a re-establishing forest. Nature 400, 56-58.

Sakamoto, K., Oba, Y., 1994. Effect of fungal to bacterial biomass ratio on the relationship between $\mathrm{CO}_{2}$ evolution and total soil microbial biomass. Biology and Fertility of Soils 17, 39-44.

Sanchez, F.G., Bursey, M.M., 2002. Transient nature of rhizosphere carbon elucidated by supercritical freon-22 extraction and ${ }^{13} \mathrm{C}$ NMR analysis. Forest Ecology and Management 169, 177-185.

Sanchez, F.G., Carter, E.A., Klepac, J., 2000. Soil carbon and soil physical properties response to incorporating mulched forest slash. New Zealand Journal of Forestry Science 30, 150-168.

Sanchez, F.G., Carter, E.A., Klepac, J., 2003. Enhancing the soil organic matter pool through biomass incorporation. Biomass and Bioenergy 24, 337-349.

Sanchez, F.G., Tiarks, A.E., Kranabetter, J.M., Page-Dumroese, D.S., Powers, R.F. Sanborn, P.T., Chapman, W.K., 2006. Effects of organic matter removal and soil compaction on fifth-year mineral soil carbon and nitrogen contents for sites across the United States and Canada. Canadian Journal of Forest Research 36, 565-576.

Scheu, S., Parkinson, D., 1994. Changes in bacterial and fungal biomass C, bacterial and fungal biovolume and ergosterol content after drying, remoistening and incubation of different layers of cool temperate forest soils. Soil Biology \& Biochemistry 11, 1515-1525.

Six, J., Conant, R.T., Paul, E.A., Paustian, K., 2002. Stabilization mechanisms of soil organic matter: implications for C-saturation of soils. Plant and Soil 241, $155-176$.

Six, J., Frey, S.D., Thiet, R.K., Batten, K.M., 2006. Bacterial and fungal contributions to carbon sequestration in agroecosystems. Soil Science Society of America Journal 70, 555-569.

Söderström, B.E., 1977. Vital staining of fungi in pure cultures and in soil with fluorescein diacetate. Soil Biology \& Biochemistry 9, 59-63.

Söderström, B.E., 1979. Some problems in assessing the fluorescein diacetate-active fungal biomass in the soil. Soil Biology \& Biochemistry 11,147-148.

Solberg, E.D., Nyborg, M., Izaurralde, R.C., Malhi, S.S., Janzen, H.H., Molina-Ayala, M., 1997. Carbon storage in soils under continuous cereal grain cropping: $\mathrm{N}$ fertilizer and straw. In: Lal, R., Kimble, J.M., Follett, R.F., Stewart, B.A. (Eds.), Management of Carbon Sequestration in Soil. CRC Press, Boca Raton, FL, pp. 235-254.

Sollins, P., Hofmann, R., Caldwell, B.A., 1996. Stabilization and destabilization of soil organic matter: mechanisms and controls. Geoderma 74, 65-105.

Stevenson, F.J., 1994. Humus Chemistry. Genesis, Composition, Reactions. John Wiley and Sons, New York.

Swift, R.S., 2001. Sequestration of carbon by soil. Soil Science 166, 858-871.

Thiet, R.K., Frey, S.D., Six, J., 2006. Do growth yield efficiencies differ between soil microbial communities differing in fungal:bacterial ratios? Reality check and methodological issues. Soil Biology \& Biochemistry 38, 837-844.

Torn, M.S., Trumbore, S.E., Chadwick, O.A., Vitousek, P.M., Hendricks, D.M., 1997. Mineral control of soil organic carbon storage and turnover. Nature 389, 170-173.

Velvis, $H$. 1997. Evaluation of the selective respiratory inhibition method for measuring the ratio of fungal:bacterial activity in acid agricultural soils. Biology and Fertility of Soils 25, 354-360.

Wang, C.-M., Ouyand, H., Shao, B., Tian, Y.-Q., Zhao, J.G., Xu, H.-Y., 2006. Soil carbon changes following afforestation with Olga Bay larch (Larix olgensis Henry) in northeastern China. Journal of Integrative Plant Biology 48, 503-512.

Wardle, D.A., Ghani, A., 1995. A critique of the microbial metabolic quotient $\left(q \mathrm{CO}_{2}\right)$ as a bioindicator of disturbance and ecosystem development. Soil Biology \& Biochemistry 27, 1601-1610.

West, A.W., 1988. Specimen preparation, stain type, and extraction and observation procedures as factors in the estimation of soil mycelial lengths and volumes by light microscopy. Biology and Fertility of Soils 7, 88-94.

Williams, S.C., Hong, Y., Danavall, D.C.A., Howard-Jones, M.H., Gibson, D., Frischer, M.E., Verity, P.G., 1998. Distinguishing between living and nonliving bacteria: evaluation of the vital stain propidium iodide and its combined use with molecular probes in aquatic samples. Journal of Microbiological Methods $32,225-236$. 